\begin{tabular}{c} 
Review of \\
ECONOMICS \\
and \\
INSTITUTIONS \\
\hline
\end{tabular}

\title{
Institutions and Economic Reforms
}

\author{
Wendy Carlin \\ University College London and CEPR
}

\begin{abstract}
Recent studies in economic development seek to establish that institutional quality is an important determinant of long-run living standards. Moreover, it appears that property rights institutions are causal for development whereas contracting institutions affect the nature of financial intermediation in the economy. I use these results to explore two questions. If property rights institutions matter for economic growth, can they help explain large-scale reform surprises? The reforms in Western Germany in 1948 are viewed as 'miraculous' whereas those in the early 1990s in the former Soviet transition economies are viewed as disappointing. I argue that the former had a limited task because they only had to restore existing property rights institutions whereas the latter had to create new ones and find new owners for assets. The second question is whether the persistence of variety in contracting institutions across countries that have developed successfully has implications for the design of financial and corporate governance reforms.
\end{abstract}

JEL classification: P11, P14, P21

Keywords: economic reforms, transition, property rights, contracting institutions, Currency Reform

\section{Introduction}

How do the quality and nature of institutions affect the efficacy of economic reforms? Economic reforms do not always work as expected. The economic reforms implemented in the Western zones of Germany in 1948 were frequently described as having a 'miraculous' effect. The postcommunist economic reforms introduced in the early 1990s across the economies of Central and Eastern Europe and the former Soviet Union led to an unexpected collapse in output and protracted recovery. I shall argue that how well reforms work depends on their compatibility with the

I am grateful for feedback from audiences at UCL, EACES, and Oxford, and to Maximilian Hirn for research assistance.

Author Address: Department of Economics UCL, Gower St, London, WC1E 6BT (Phone: +44-20-76795858, Fax: +44-20-79162775; Email: w.carlin@ucl.ac.uk)

\section{Recommended Citation}

Carlin, W. (2010). Institutions and Economic Reforms. Review of Economics and Institutions, 1 (1), Article 2. doi: 10.5202/rei.v1i1.2. Retrieved from http://www.rei.unipg.it/rei/article/view/2 
institutions that exist in the economy. The surprise associated with each of these reform episodes suggests that this relationship is not well understood: the key difference between Germany in 1948 and Eastern Europe in 1990 is that in the former but not the latter there was institutional continuity and compatibility between the reforms and preexisting institutions.

Much of the existing literature on large-scale reforms prompted by the post-communist experience has focused on the sequencing of reforms and the political economy of 'big bang' versus 'gradualist' strategies (e.g., Dewatripont and Roland, 1996; Roland, 2000). The aim of this paper is to redirect attention to the content of reforms and in particular to connect this debate to the recent literature in development economics, which seeks to identify the institutions that are causal in long-run capitalist development.

Recent cross-country econometric analysis (e.g., Acemoglu et al., 2001) is widely viewed as having established that institutional quality is causal in determining living standards (e.g., Pande and Udry, 2005). More recently, Acemoglu and Johnson (2005) have sought to 'unbundle' institutions and clarify which institutions matter for which outcomes. In contrast to North (1981), who argued that both property rights institutions and contracting institutions were central to economic development, Acemoglu and Johnson find that it is property rights institutions that matter for living standards. Contracting institutions, on the other hand, appear to influence the form of the financial system, e.g. whether the stock market is important in the economy.

An interpretation of the Acemoglu and Johnson finding is provided by a different tradition of inquiry in political science, which identifies a number of 'varieties of capitalism' (e.g., Hall and Soskice, 2000). In the varieties of capitalism literature, the starting point is the co-existence of a set of highly developed economies operating in open financial and goods markets, which share secure property rights but which differ across a number of other institutional dimensions, one of which is the role played by the stock market. Other dimensions of difference are patterns of ownership concentration, the regulation and organization of the labour market, education and training institutions, and the nature of the welfare state.

From this perspective, contracting institutions are a determinant of which variety of capitalism prevails but not of long-run growth. This may help to explain why in countries with different legal traditions, which form an important foundation for contracting institutions, successful development has nevertheless occurred. If successful development is consistent with a variety of contracting institutions, one hypothesis is that different contracting institutions influence comparative and not absolute advantage. This may also help to explain the persistence of these 
differences in the face of increasing integration of product and capital markets. If this conjecture is correct, there may be unanticipated consequences from the application of a uniform set of reform measures. Opposition to large-scale reforms may not simply reflect vested interests but also have an efficiency rationale.

In this paper, I explore the interaction between institutions and economic reforms by looking at the role of property rights institutions in helping to account for large-scale reform surprises and by examining whether the persistence of variation in contracting institutions across developed economies has implications for the design of financial and corporate governance reforms. Section 2 uses the empirical results of Acemoglu et al. (2001) as the basis for identifying the role of institutional quality in economic development and to separate the function of property rights institutions from that of contracting institutions in the operation and performance outcomes of capitalist economies. Section 3 compares the two examples of large-scale reform surprises introduced above: the Currency Reform in western Germany and the post-communist reforms in the former Soviet bloc economies. This comparison is used in Section 4 to examine the interaction between property rights institutions and reform outcomes. I contrast the continuity in property rights institutions and ownership structures in West Germany with the abandoning of the existing property rights institutions in the post-communist reforms in the transition economies. Consistent with the argument in Section 2, the countries that have done best are those that have created the most secure property rights. These countries have also attracted more foreign investment. Indeed the capitalism that is emerging in transition economies is unusual in its dependence on foreign owners to propel economic development. This is explored in Section 5. In Section 6, I extend the argument that reform design should be sensitive to institutions beyond the examples of large-scale reform by examining the interaction between contracting institutions and economic reforms.

\section{Property Rights Institutions and Contracting Institutions}

There has been a recent revival of interest in the role of institutions in long-run economic development (North, 1993). A very widely cited empirical paper is Acemoglu, Johnson and Robinson (AJR, 2001). In this paper the authors provide econometric evidence for the causal role of institutional quality in growth. They propose an ingenious way of overcoming the central problems for inference presented by the small sample size of countries in the world, the limited within country variation 
in institutions, the reverse causality from good economic performance to better institutions, the omitted variables likely to influence both institutional quality and growth, and the difficulty of measuring institutional quality. Their strategy is to find a variable that was a determinant of the quality of early institutions but that has no direct effect on current living standards. By selecting a sub-sample of countries in the world that had been colonized, they are able to use the disease environment faced by potential colonizers as their instrumental variable. The conjecture is that the disease environment affected the nature of the colonies that were established but has no direct effect on living standards today. They hypothesise that where the disease environment was conducive to European settlement, so-called settler colonies were established. Settlers replicated their home institutions, which were associated with secure property rights and with successful capitalist development. The persistence of these high quality institutions is reflected in current institutional quality.

By contrast in places where the disease environment for Europeans made settlement hazardous, extractive states were set up with the main purpose of transferring resources back to the colonial power. Australia is an example of a settler colony in which institutions to enforce the rule of law were paramount. The Belgian Congo was an extractive colony, where the disease environment made it unattractive for the colonizers to settle and invest in replicating home institutions. To complete the argument, AJR point out that the disease environment at the time of potential settlement is not related to current living standards because on the one hand, indigenous populations were already largely immune to the diseases that killed Europeans and on the other that these diseases are no longer major killers.

The magnitude of the estimated effect of institutions is large: AJR's results suggest that improving Nigeria's institutions to the level of Chile's would produce a long run increase in Nigeria's per capita income of up to seven-fold. This accounts for over $60 \%$ of the existing gap between these two countries. Although some doubts have emerged about the settler mortality data and some of the assumptions made by AJR in matching this data to the countries in the sample (see Albouy, 2005, and the response by Acemoglu, Johnson and Robinson, 2005), the judgement that potential settler mortality is a good instrumental variable for institutional quality has probably strengthened over time (e.g., Murray, 2006). More broadly, the consensus view presented by Pande and Udry (2005), who provide a fairly comprehensive survey of empirical studies conducted in the past decade, is that the accumulation of evidence from the cross country 
studies supports the conclusion that institutional quality matters for long run growth ${ }^{1}$.

In the studies surveyed by Pande and Udry, a range of variables are used to proxy institutional quality. Acemoglu and Johnson (2005) follow up their earlier analysis by attempting to differentiate between two generic types of institutions and their effects. Property rights institutions are those that regulate the relationship between the producers and lenders in the economy on the one hand and on the other, the state or other groups in the economy with power, so-called elites. Contracting institutions regulate the relationship between two groups of private sector agents, the users of finance (producers) and those who supply it. They take issue with North's view that it is a combination of so-called property rights institutions and the institutions that regulate private contracts that is crucial for development.

As a proxy for the quality of property rights institutions Acemoglu and Johnson use a measure of the risk of expropriation of foreign investors and as a proxy for contracting institutions, a measure of the number of steps required to resolve an unpaid cheque. Contracting institutions are more costly when the degree of legal formalism is higher - as measured here by the number of steps taken to clear a bounced cheque. The empirical strategy for separating the impact of the two types of institution rests on finding a different instrumental variable for each institution. They first establish the intuition for their strategy, which rests on the role of European colonizers. The idea is that colonizers brought with them their legal institutions so that the identity of the colonial power determines the legal code of the colony. Moreover, legal formalism and hence contracting institutions vary across the different legal codes. They go on to argue, however, that the legal system introduced at colonization does not determine property rights institutions today. Rather, applying the logic from AJR, it was the disease environment facing potential settlers that affected whether a settler or extractive colony was established and hence the quality of property rights now - it had no effect on the nationality of potential colonizers and thus did not affect the degree of legal formalism observed today. Hence the nationality of the colonizer (and the legal code they brought with them) is the instrumental variable for legal formalism (contracting institutions) and the disease environment facing potential settlers (how colonization was carried out) is the instrumental variable for property rights institutions.

After establishing the validity of the instrumental variables for each institution, the key results supporting the 'unbundling' hypothesis come

${ }^{1}$ For recent evidence on the magnitude of the effect of institutions on growth using firm level data from about 100 countries, see Carlin et al. (2010). 
from tests where both property rights and contracting institutions are included together in regressions with a performance measure as the dependent variable. This reveals that property rights institutions matter for GDP per capita, the ratio of investment to GDP, broad financial development as measured by the ratio of credit extended to the private sector (as a proportion of GDP) and stock market development, whereas contracting institutions matter only for the form of financial intermediation as proxied by stock market development.

This finding resonates with a much older literature in economics associated with Gerschenkron (1962) and a current debate mainly in comparative political science (Hall and Soskice, 2001), which seek to account for the role of different types of financial institutions in the development of the advanced economies. The 'varieties of capitalism' literature focuses specifically on how to explain the coexistence of advanced economies at similar levels of development (and of property rights enforcement) with different clusters of institutions including financial institutions. Data collection exercises over the past decade (e.g., cross country measures of the structure of ownership of non-financial companies; the number of steps required to clear a cheque or evict a tenant) led by La Porta, Shleifer, Djankov and colleagues have confirmed the variation in contracting institutions even within the advanced OECD economies.

\section{Reform Surprises}

On the basis of the empirical support for the importance of property rights institutions in the development process, we turn to the possible role of these institutions in the efficacy of large-scale economic reforms. A famous example of an unexpectedly successful large-scale economic reform was the Currency Reform and associated liberalization measures introduced in the British and US administered zones of occupation of Germany in June 1948. At the time the economy was dominated by a complex form of barter trade, the vestiges of the Nazi command economy and the black market. Shortages of all kinds were pervasive and levels of absenteeism from work were very high (Carlin, 1989). The reforms were introduced on June $30^{\text {th }} 1948$ and in its report published on $3^{\text {rd }} \mathrm{July}$, The Economist provides a vivid description of the immediate consequences:

Housewives strolled down the streets gazing in astonishment at shop-windows at shoes, leather handbags, tools, perambulators, bicycles, cherries in baskets, young carrots tied in neat bundles. In the early morning, farmers had been seen making their unaccustomed way into town with produce for sale, a little uncertain what were the legal channels for selling it. 
On the third working day after the currency reform, manufacturers in Nuremberg said that absence from factories from all causes had fallen from 18 to 20 per cent to 2 or 3 per cent.

The reforms comprised a currency reform that replaced the existing Reichsmark with the Deutschmark and liberalized prices and wages. The Reichsmark had become useless as functioning money due to a combination of controlled prices, an expansion of the stock of money by the Nazi authorities and the low level of output. Following the collapse of the regime in 1945, the occupation authorities kept the price controls in place with the consequence that excess money was reflected in repressed rather than open inflation. The presence of dysfunctional money resulted in the development of elaborate networks of bilateral transactions as producers sought to re-establish supply chains after the collapse at the end of the war in a sophisticated industrial economy based on a complex division of labour (Carlin, 1989). Alongside this bilateral exchange or barter economy, a black market developed in which a range of commodities provided a means of exchange. The remainder of the economy continued to operate with controlled prices and with allocations directed by the occupation authorities (Abelshauser, 1975 and 2004).

Figure 1 shows the path of industrial output from the fourth quarter of 1945 to the third quarter of 1949. Modest recovery on the basis of the lowlevel economic mechanisms described above is shown (see Carlin, 1989, for further details): from its nadir of less than one-fifth of the 1936 level, industrial output had recovered to over one-half by mid 1948 (Abelshauser, 1975). The pace of the recovery of output picked up after the Currency Reform in mid 1948. However, the investment series provides a more convincing indicator of the change in the nature of economic activity. Gross investment in industry remained very weak until the Currency Reform: it was below the level required to maintain the net capital stock. Following the Currency Reform however, the level of investment jumped above its pre-war level and continued to grow strongly through 1949 (see Figure 1). 
Figure 1 - Western Germany: Industrial Output and Gross Investment, 1945:4-1949:3

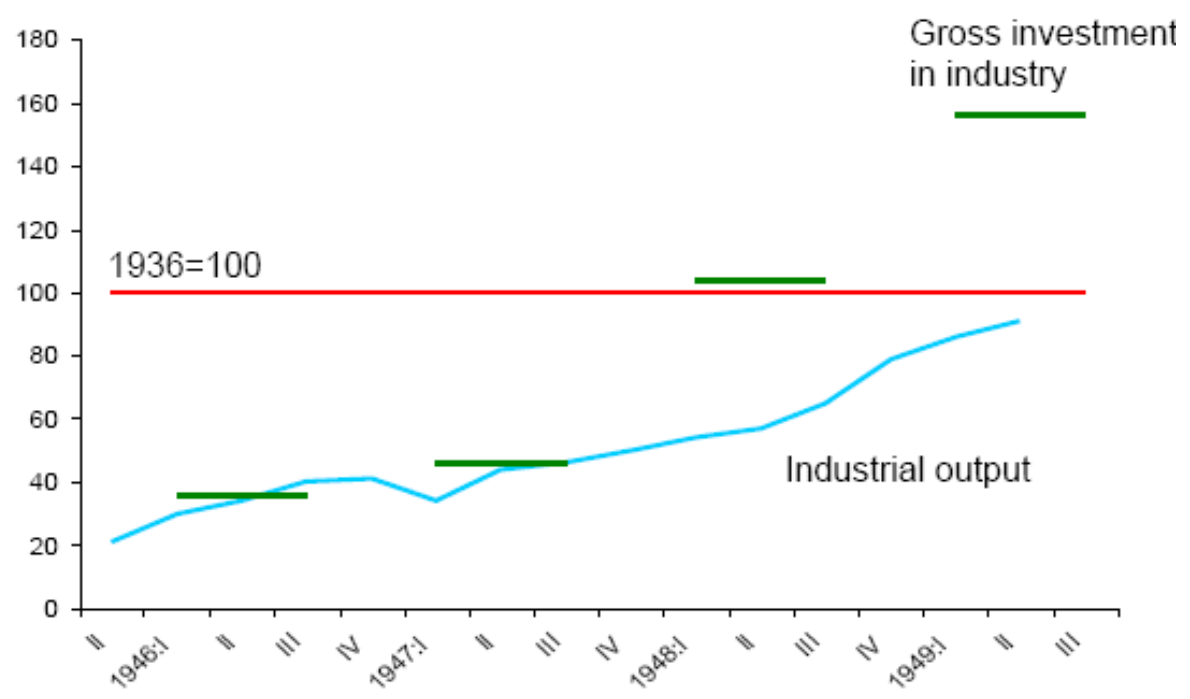

Sources: Abelshauser, 1975; Krengel, 1958; Carlin, 1989.

The recovery of investment marked the return of long-term decisionmaking by managers and the economy of western Germany began a process of rapid return to its long-term growth path (see Figure 2). Figure 2 shows GDP per capita in constant Geary-Khamis dollars at purchasing power parity for the UK and West Germany over the period from 1900 to 1990. Germany's growth path is punctuated by the two wars and the Depression but returns rapidly to its long-run path after the Currency Reform (see also Eichengreen and Ritschl, 1997).

Figure 2 - GDP per Capita (PPP), West Germany and the UK, 1900-1990

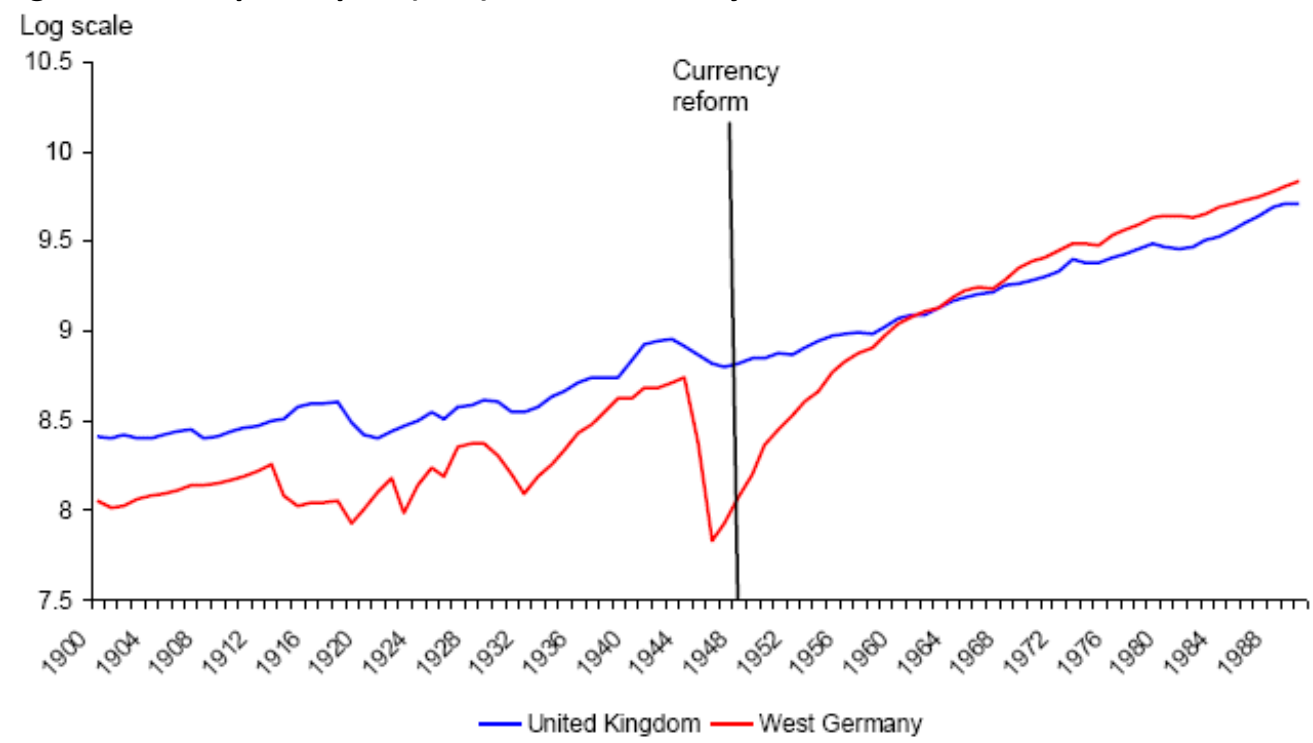

Source: Maddison, 1995; Groningen database, 2005. 
My second example of a reform surprise is the post-communist transition. Figure 3 presents long-run data from the same sources as Figure 2, this time for Austria, Czechoslovakia / Czech Republic and Hungary. The data runs from 1924 to 2005. These three economies were fairly similar in terms of living standards in the mid 1920s, when the gap between Austria and Czechoslovakia was similar to that between the UK and Germany.

Figure 3 - GDP per Capita (PPP), Austria, Czech Republic and Hungary, 1924-2005

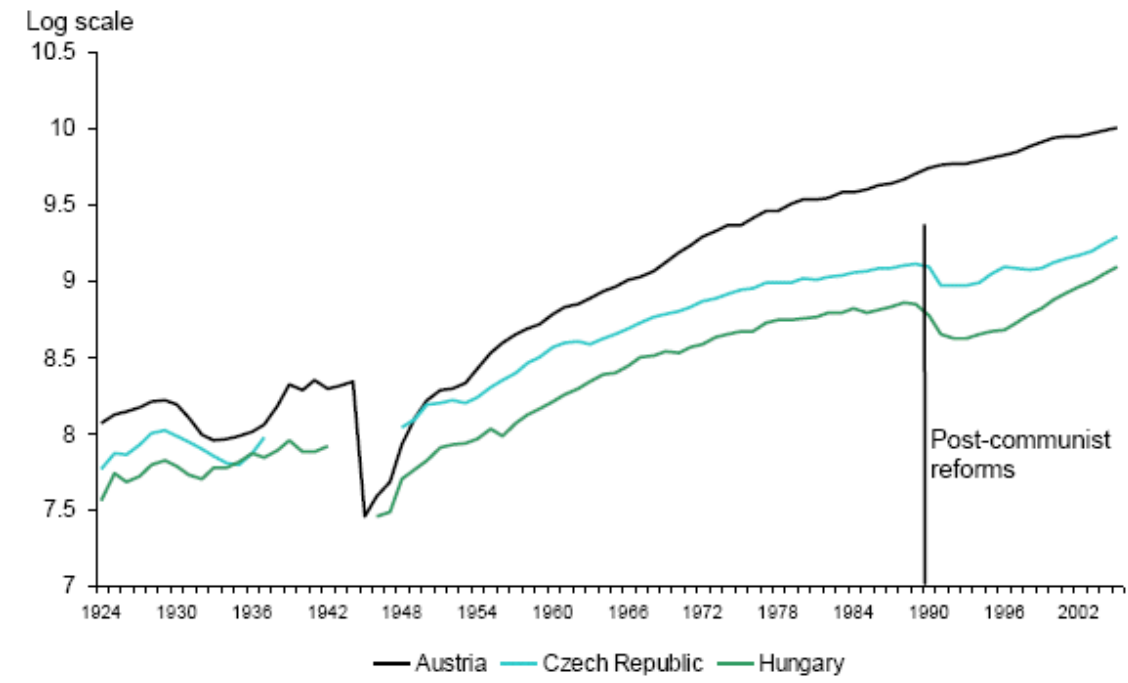

Source: Maddison, 1995; Groningen database, 2006.

The delayed post-war recovery in the communist economies and subsequent divergence in living standards from Austria after 1950 is clear from Figure 3. I focus on the post-communist reforms: output per capita dropped sharply and did not recover its pre-reform level for almost a decade. Although Austria itself was growing very slowly after 1990, as Fig. 3 illustrates reform in the Czech Republic and Hungary was not followed by a strong pull of these two economies back to their long-run growth path of GDP per capita as defined by Austria.

Additional insight into the pattern of post-reform growth is provided by looking across regions within the transition economies. Figure 4 provides regional data on GDP per capita in 1995 and 2006 compared with the EU average for three of the advanced transition economies: Poland, Czech Republic and Hungary, with Austria as the comparator. 
Figure 4 - GDP per Capita by Region 1995 and 2006: EU average $=100$
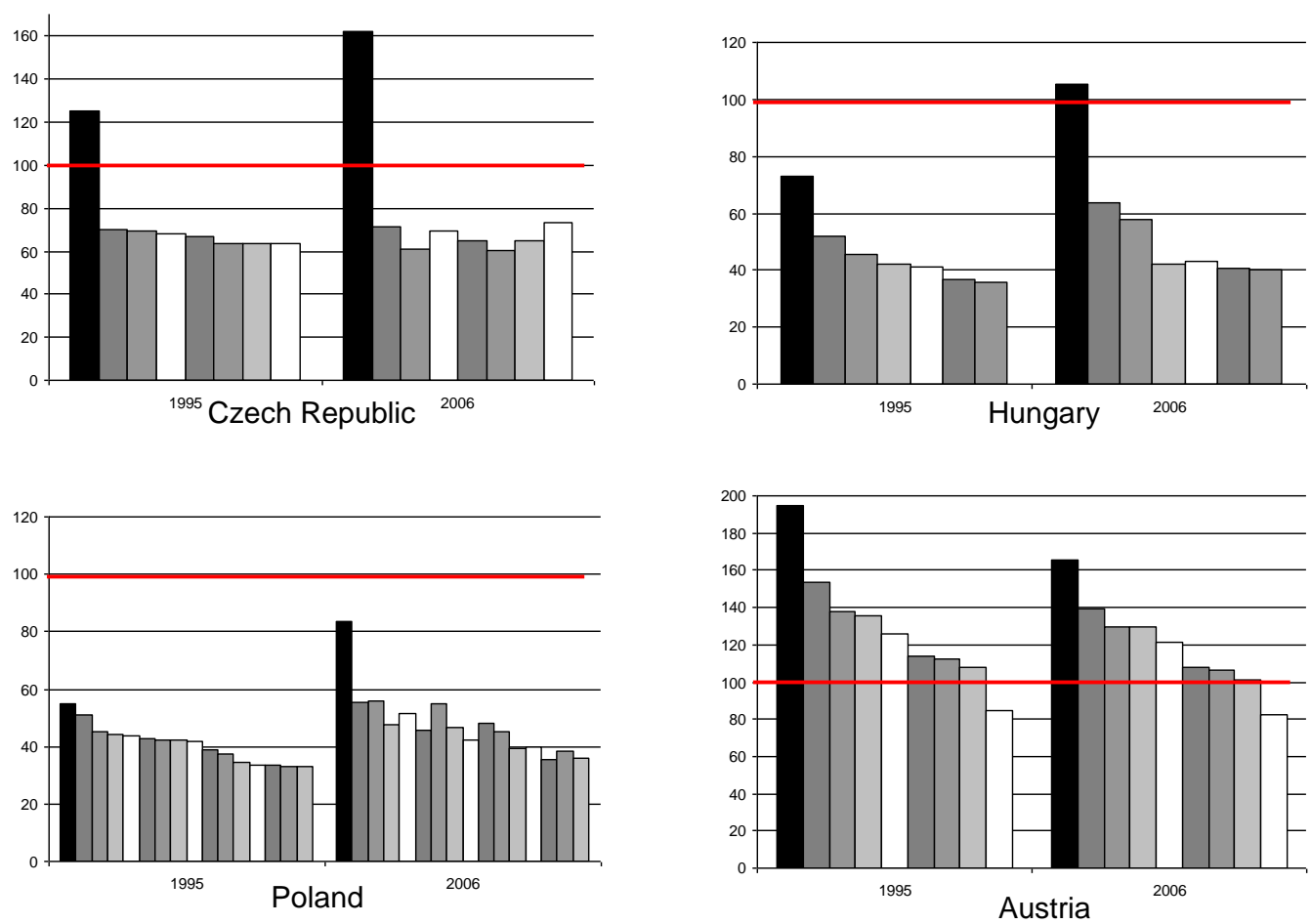

Source: Eurostat NUTS2 Regional GDP per capita in PPP.

Notes: In each country, regions are ordered from highest GDP pc in 1995 from left to right; regions are in the same order in 2006.

Whilst persistent regional dispersion characterizes Austria as well as the transition economies, the striking feature of the three transition countries is that whereas the region containing the capital city converges strongly toward the EU average (or in the case of the Czech Republic toward the Vienna region's GDP per capita), the other regions show much slower convergence. This pattern suggests that the weakness of the overall convergence of the Czech Republic and Hungary to Austria's GDP per capita shown in Figure 3 is a phenomenon of the non-capital city regions.

The substantial fall in GDP per capita following the post-communist reforms was common across the former Soviet bloc transition economies. For illustrative purposes, Figure 5 shows the largest economy in each of three broad country groupings (central and eastern European countries including the Baltic states, south eastern Europe, and the Commonwealth of Independent States) along with the weakest performers in the first and third groups, Lithuania and Tajikistan. The performance of East Germany is also shown. Transposed onto the graph is the performance of West Germany from 1948 to 1966 (with its 1936 level of GDP per capita set at 1). 
Figure 5 - Post-reform GDP per capita (PPP). West Germany (1936=1) 1948-1966;

Transition countries $(1990=1)$

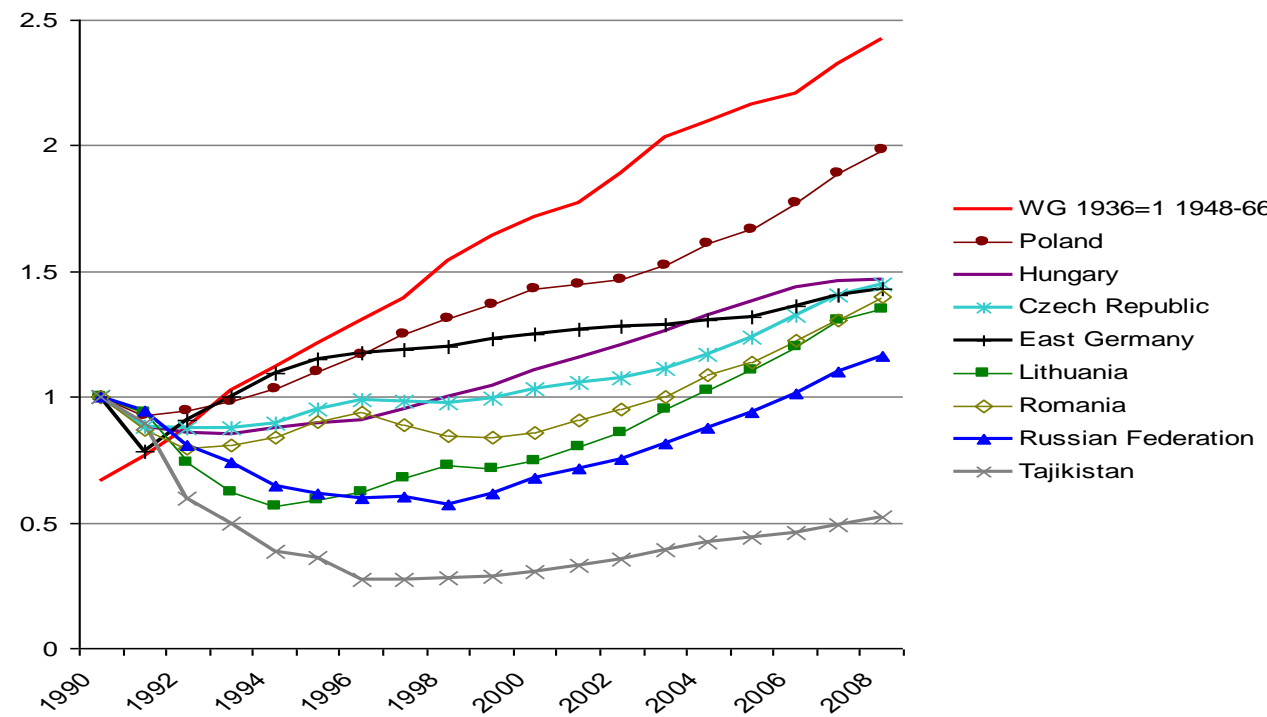

Source: The Conference Board and Groningen Growth and Development Centre, Total Economy Database, June 2009,http://www.conference-board.org/economics/

East Germany linked to St. Bundesamt (2009) Bruttoinlandsprodukt, Bruttowertschöpfung in den Ländern und Ost-West-Großraumregionen Deutschlands 1991 bis 2008.

Just as a boom was not expected to follow the Currency Reform and price liberalization in West Germany, a collapse in output was not predicted for post-communist transition economies. The analysis in Section 2 highlights the importance of property rights institutions in economic growth. This suggests that poorly understood differences in the necessary institution-building of the respective reforms may help explain why the outcomes were unexpected.

\section{Property Rights Institutions and Large-Scale Reform Surprises}

Institutions are 'the laws, informal rules, and conventions that give a durable structure to the social interactions among the members of a population' (Bowles, 2004) and although economic reforms may change the rules overnight, as North points out, 'the informal norms change only gradually. Since it is the norms that provide "legitimacy" to a set of rules, revolutionary change is never as revolutionary as its supporters desire and performance will be different than anticipated' (North, 1993). Two features of these definitions seem especially relevant for understanding the interaction between institutions and reforms. Both authors stress the importance of informal norms in addition to the law on the books and the 
formal institutional apparatus. They also hint that creating institutions is a slow business.

In the case of the reforms in Germany in 1948, behaviour did change 'overnight' and with it the functioning of the economy. As noted above, stocks of goods were brought out for sale, workers returned to regular working patterns and firms began to invest in new plant and equipment. In the wake of the post-communist reforms, the change in the rules produced a collapse in output and slow recovery. As Figures 4 and 5 show, unlike West Germany, even the most successful post-communist transition economies did not return rapidly to a long-run growth path defined by pre-war comparators after the implementation of large-scale reform. I argue that the reforms in Germany worked well and quickly because what they had to do - in institution-building terms - was modest. The function of the reforms was to enable the pre-existing institutions of a capitalist economy to function again. The task was not to create new rules of the game but to restore old and well-understood ones. By contrast, the reforms in transition had a much larger job to do - to create the institutions of a capitalist economy and the associated norms of economic behaviour where they had not existed for at least a generation.

There has been much debate among economic historians as to the significance of the 1948 reforms in West Germany's post-war renaissance (e.g., Abelshauser, 1975, 2004; Ritschl, 1985; Buchheim, 1988). Both the time series data and contemporary reports documenting economic behaviour point toward two key 'turning points' in the process of recovery. The first was in 1947 with the announcement of the Truman doctrine. This confirmed that the western zones of Germany were to be rehabilitated as a market economy, on the economic strength of which the US and its allies could depend as a bulwark against communism. The objective of promoting West Germany's reintegration in the international trading system within the US's sphere of influence displaced both the original intention in the British zone to strengthen the residual war-time command economy along planning lines and of the Americans to deindustrialize their zone and return it to an agrarian economy. The Truman doctrine and associated economic policy decisions created the preconditions for the restoration of growth but for this to happen would require that functioning money be reintroduced and prices and wages be liberalized from the levels fixed in 1936. This was accomplished by the reforms of mid 1948: the second turning point.

Placed in the context of the analysis of the role of institutions in growth discussed in Section 2, it was the Truman doctrine that first signalled enhanced security of property rights in post-war western Germany. The state (through the governing Allied authorities) indicated that it would not expropriate the owners of private property. This was reinforced by the 
redistributive effects of the Currency Reform in which debts (government and private) were massively written down in value but the real value of equity was maintained (Carlin, 1996). Observers at the time noted how firms sought to maintain their old relationships with suppliers and customers via complicated bilateral trades between the collapse of the economy in 1945 and the Currency Reform ${ }^{2}$. The growth of economic activity was restricted by the absence of clarity about property rights and of functioning money but the underlying relationships between private sector agents were largely intact and formed the basis on which rapid growth could later take place.

Recent research has confirmed continuity in the identity of owners of German companies through the interwar and Nazi periods into the postwar years (Fohlin, 2005). Ownership concentration increased through the Nazi period as (gentile) founder families were assisted in retaining control. Continuity in personnel has been demonstrated in owners ${ }^{3}$, managers, the chambers of commerce and industry and in the employers' and industry associations (Erker, 1999; Joly, 2000; Wiesen, 2001). Fohlin reports that "the deconcentration efforts of the allies in the early aftermath of World War II - both in terms of equity ownership and industrial organization - failed generally over the long run" (p.13). This is even the case in sectors targeted by the Allied authorities for post-war 'deconcentration' and 'denazification': steel, coal, chemicals, insurance and banks (Borkin, 1978; Erker, 1999; Feldman, 2001; Frei, 2003; Horstmann, 1991; Pohl, 1974). With owners and managers largely in place, investment decisions were made once expropriation by the state had been ruled out, functioning money was again available, and prices could be set to deliver the required profit margins.

The same fundamental rules of the game in terms of the relationship between the private sector and the state and between private sector agents were re-established in post-war West Germany as in the pre-war period: a capitalist economy was restored with contracting institutions based on the existing civil law tradition. Moreover as we have seen, many of the informal norms and the relationships sustained by them had remained intact albeit through inefficient non-market mechanisms. The Currency Reform served to reactivate pre-existing property rights institutions and

2 The scope for and limits to recovery in the period between the collapse and the Currency Reform are analysed using Kornai's concept of 'autonomous control' in Carlin (1989).

${ }^{3}$ Fohlin (2005) explains that the difficulties in providing a comprehensive documentation of this arise because firm-level ownership data are largely absent for the pre World War II period - public companies issued bearer shares and there was no requirement to make public the identity of owners. 
allowed 'business as usual' to return. The rapid response of output and investment reflected this. By contrast, the post-communist reforms in Eastern Europe and the former Soviet Union were to require a 'Great Transformation' (Kornai, 2006). There was a discontinuity in institutions with new rules of the game coming into play. For most transition economies property rights institutions played no significant role in the economy prior to the reforms.

The scale of the task in creating property rights institutions that had to be accomplished by the post-communist reforms was underestimated. John Williamson's characterization of the Washington consensus (1990) devotes just two sentences to the issue of property rights: "In the United States property rights are so well entrenched that their fundamental importance for the satisfactory operation of the capitalist system is easily overlooked. I suspect, however, that when Washington brings itself to think about the subject, there is general acceptance that property rights do indeed matter." In the prevailing reform circles priority was given to macroeconomic stabilization and to the swift replacement of the state by private owners of enterprises. When combined with freeing prices and weakening governments, the presumption was that a space would be opened up in which a market economy would spontaneously emerge (see also Roland, 2000).

One of the under-explored aspects of the post-Soviet transition is the reasons for the fall in output. Many accounts of the output collapse focus on relative price changes (such as the withdrawal of subsidies and the move to world prices in international trade) or on excessively tight macroeconomic policy. Neither of these explanations refers to the role of institutions: the analysis applies standard tools of policy analysis as would be appropriate in a functioning market economy. By contrast, the term 'disorganization' has been used in models that attempt to capture the micro-mechanisms behind the output collapse caused by the shift from one mode of economic organization to another (e.g., Blanchard and Kremer, 1997, Roland and Verdier, 1999). Blanchard and Kremer note that under planning, production was organized around bilateral relationships between producers and purchasers in the sense that each producer had a relationship with only one buyer of a particular product. Knowledge about and availability of alternative suppliers was largely absent. Given a complex division of labour, many inputs are required for an enterprise to produce a given product. Following the cessation of central planning, enterprises had to secure access to each input in the absence of the preexisting administrative arrangements. The problem is that in the absence of planning, suppliers have improved alternative opportunities (e.g., to supply new private firms) and the state firm becomes enmeshed in a series of bargaining problems. Since such problems exist for all inputs, the more 
complex is production, the larger the number of such bargaining problems and the more likely a given product cannot be produced. Hence, the expected fall in output is greater for more complex production processes.

Roland and Verdier suggest other mechanisms that may have produced the fall in output: the process of finding new suppliers (and customers) was inhibited by search frictions and investment specificity. Hence relationship-specific investments could only occur after a new long-term partner had been found. In the interim, output would fall. The role of disorganization in the output collapse has not been quantified but corroborative evidence of its importance is provided by the fact that the largest output falls across the transition economies occurred in 1991, the year when trading arrangements in the CMEA were abandoned and trade took place at world prices (Blanchard, 1997).

Unlike the Chinese reforms where a dual-track strategy retained the 'plan track' whilst allowing a market track to develop alongside, the former Soviet countries chose a single track reform, which involved a leap to a capitalist economy. This is the sense in which Kornai (2006) labels the Chinese reforms as 'slow' and the former Soviet bloc ones as 'fast'. Qian (2003) provides an analysis of Chinese reform success in the absence of clarity of property rights that in many ways is consistent with the arguments presented here. The dual track provided institutional continuity and allowed the Chinese to avoid a 'transitional recession' as Figure 6 illustrates.

\section{Figure 6 - GDP per Capita and Large-Scale Reforms: China, USSR and Russian Federation, 1970-2004

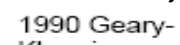

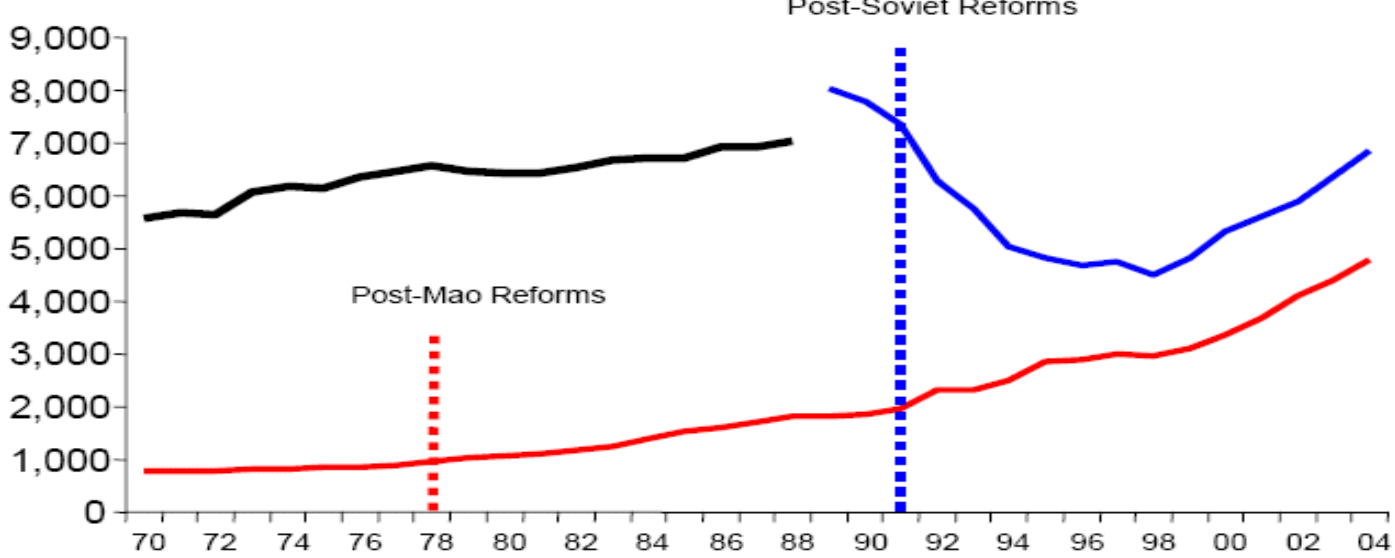

- China - USSR — Russian Federation

Source: Groningen Total Economy Database, 2006, http://www.ggdc.net; GDP per capita measured at PPP in 1990 Geary-Khamis International Dollars. 
Both stand in stark contrast to post-war West Germany where the norms of a capitalist economy had legitimacy and where firms had owners and managers who were ready to resume activities. In contrast to Eastern Europe, supplier-producer relationships in Germany were also largely intact - as noted above, elaborate chains of bilateral arrangements had helped to sustain such relationships during the interregnum before the Currency Reform. The institutional vacuum at the outset of the East European transition helps explain why transition has proved more difficult with much slower catch up than had been widely anticipated at the outset. As we shall see in the next section, it also helps explain why foreign owners are playing such an important role in the form of capitalism that is emerging in these economies.

\section{Security of Property Rights and the Role of Foreign Owners in Transition}

Successful transition depends on solving the problem of the relationship between the state and firms - both in the sense of limiting the threat of expropriation by the state (or elites) of private firms and in preventing the state from bailing out unprofitable activities. It also depends on finding new owners for productive assets. Not only are new rules required but the roles of the different players in the game have to be allocated as well. Two distinct mechanisms operated in the allocation process: the creation of new firms and the privatization of existing large enterprises. As it is emerging in the post-Soviet economies, capitalism in transition is unusual in its dependence on foreign ownership of large firms.

The fifteen years of transition have provided much evidence of the emergence of a process of creative destruction 'from below'. Small-scale privatization of shops, permission for new businesses to open, the introduction of competition from imports and limits on the bail-outs of loss-making firms by government produced the environment in which a Schumpeterian process of creative destruction could develop. All firms and potential firms faced innovation opportunities and there is some evidence that firms facing rivals innovated more - more than monopolists and more than those facing a lot of competition (Carlin et al., 2004). The many empty niches in small scale production and services began to be filled. A multi-country study of exit, entry and within-firm productivity growth reports that resources are moving in transition economies to new and to more productive firms (Bartelsman et al., 2004), confirming the productivity enhancing character of creative destruction. The study also 
found that the process was less effective in the least advanced transition economy in their sample (Romania).

But the emergence and growth of new $a b$ initio firms was too slow to prevent the collapse of aggregate output when the planned allocations of inputs and outputs were abandoned both within each economy and the international level. Finding effective owners for large firms proved more problematic than stimulating the creation of new small ones. A wide variety of methods of privatization were implemented across the region and a large body of empirical evidence has accumulated from tests of the effects of privatization on enterprise performance. Hanousek et al. (2007) summarize the results from the past fifteen years, which range from the agnostic (e.g., Bevan et al., 1999, report a wide variety of results with no systematic impact of privatization on performance), through the mildly positive findings of Megginson and Netter (2001) from an assessment of studies of privatization across the world, to the firmer conclusion of Shirley and Walsh (2000) and Djankov and Murrell (2002) that privatization has a positive effect on performance. Hanousek et al. point to three key problems with the studies of privatization effects in transition: the evaluation of short-run effects only, variable data quality, and the unsystematic treatment or neglect of selection and associated endogeneity problems due to the design of privatization programmes in which enterprises of different quality were treated differently.

The most recent comprehensive evaluation of the effects of privatization of state-owned enterprises in transition economies is Estrin et al. (2009). Their conclusions reflect evidence coming from more recent studies that deal better with the problems described above. This newer evidence suggests that it cannot safely be concluded that privatization per se has a marked positive effect on firm performance. However, the earlier evidence that foreign owners have a positive effect on performance (especially when the foreign owner is an industrial firm and when it has a strategic stake) survives more recent testing. The size of the effect is smaller in some more recent studies than previous ones suggested, where proper corrections were not made in the estimation procedure for the likely purchase of better firms by foreign owners. These new results serve to highlight the difficulty of finding owners, managers and effective governance structures for large firms. They indicate that foreign strategic owners are the only types who produce clear performance improvements as compared with continued state ownership.

AJR use the threat of expropriation of foreign firms as their indicator of property rights protection and find that strong property rights bring high GDP per capita: institutions cause development. An interesting twist to this hypothesis from the transition experience is that there is growing evidence of the way the presence of foreign firms directly affects 
productivity levels. As better quality institutions have developed, the presence of foreign firms has increased and the productivity levels of foreign-owned firms are higher than those of domestic ones. What was not anticipated was the extent to which foreign owners would be relied on to raise productivity in large firms.

In comparisons of the role of foreign affiliates in turnover and employment in manufacturing and services in OECD countries, data for three transition countries is reported (Czech Republic, Hungary and Poland) for $2001 / 2$. For services, these three countries rank in the top six countries (out of 19 or 20) for the share of foreign affiliates in turnover and employment and in the top eight countries (out of 21 or 22) for manufacturing $(\mathrm{OECD}, 2005 \mathrm{a})^{4}$. In a completely different data-set covering firms listed on the world's stock exchanges, the advanced transition economies stand out in the extent of the presence of foreign-owned firms amongst listed firms and in the size of their stakes. The Czech Republic, Hungary and Poland are in the top three out of four places on each measure (data-set from Carlin et al., 2007).

In some of the smaller advanced transition economies, foreign-owned firms dominate the landscape among larger firms. For example, in the Czech Republic in a sample covering 70\% of employment in large firms in industry (with more than 100 employees), one half of employment is in foreign-owned firms in 2000 (Sabirianova et al., SST, 2005a, 2005b). Even in the much larger and more closed economy of Russia, almost one-fifth of employment in large firms in industry is in foreign-owned ones.

To understand the implications for the economy of foreign ownership, it is necessary to disentangle three channels: Do foreign firms have higher productivity because foreign owners are able to buy the most productive domestic firms? Does ownership by a foreign company raise the productivity of domestic firms they acquire (or of domestic assets in green-field operations) bringing it closer to the world frontier? Does foreign ownership affect the productivity of related firms in the host economy?

Relatively few studies have been able to provide evidence on these questions because of the demanding requirements on data. SST's study of the Czech Republic and Russia is an important bench-mark but judging the extent to which what they find represents the broader picture across transition must wait for replication studies in other countries. The evidence across transition economies shows that productivity levels of foreign-owned firms are significantly higher than those of domestic private and state-owned firms (see, for example the studies cited in SST 2005b). From their data, SST estimate that foreign owned firms are much

${ }^{4}$ For further discussion of the data, see OECD (2005b). 
more efficient (i.e., have higher multi-factor productivity) than stateowned firms, with the range for the Czech Republic being from 30 to $90 \%$ higher and in Russia from 20 to $170 \%$ higher depending on the estimation method used. Domestically owned firms are found to be only about $10 \%$ more efficient than state-owned ones in the Czech Republic and not clearly distinguishable in Russia.

Their results indicate that although foreign firms tend to acquire more productive domestic firms, this 'cherry picking' effect is of relatively minor quantitative significance in accounting for the superior performance of foreign owned firms. They find that foreign firms enter at a higher level of efficiency than domestic firms and catch up over time to the productivity frontier as defined by the best-performing foreign-owned firms in the industry in the host country. In a given industry, domestic firms do not catch up to the frontier. As a consequence, foreign firms increasingly displace domestic firms in the upper part of the efficiency distribution of firms. Based on existing evidence large domestic owned firms find it difficult to catch up to the international productivity frontier and this is not helped by the presence of foreign firms in the same industry - contrary to what has been found for firms in the UK in the presence of foreign-owned counterparts (Griffith et al., 2003). Catch-up in the large-firm sector is therefore dependent on the direct productivity raising effect of the presence of foreign owned firms. One implication given the limits to the supply of potential owners in the world economy is that aggregate catch-up will be easier for smaller than for larger economies. More broadly, a key question is how the presence of foreign firms affects institution-building itself.

\section{Institutions and Economic Reforms Interact: Contracting Institutions}

An understanding of the role of institutions is relevant not only to the explanation of large-scale reform surprises but also to the design of reform programmes such as corporate governance and financial sector reform initiatives. I return to Acemoglu and Johnson's core finding that countries with a lower degree of legal formalism tend to have bigger stock markets but that there is no significant relationship between legal formalism and economic development or overall financial development as measured by the ratio of credit to the private sector to GDP. They suggest that a high level of legal formalism does not prevent development because private agents can find ways of mitigating its effects. For example debt may be substituted for equity as a source of external finance since debt contracts are cheaper to enforce where contracting institutions are weaker or agents 
will rely more on informal relationships (implicit contracts). This is not possible in the case of property rights institutions, where the role of the state is paramount. The conjecture that the variation in contracting institutions reflects cross-country differences in specialization in production suggests that there may be efficiency reasons for their persistence. If this is the case, the implications for reform will be different from those associated with contracting institutions that are simply costly.

By comparing the patenting activities of firms in two advanced economies with very different contracting institutions, we get a hint as to the role such cross-country differences may play. Germany is characterized by a relatively high degree of legal formalism: there are 50\% more legal procedures involved in resolving a bad cheque than is the case in the USA. Figure 7 displays the pattern of patenting across industries for Germany and the US using a patent specialization index calculated from the patents registered at the European Patent Office in 1992-94 for 12 countries. Industries are ranked in the figure from the top according to the scientific content of patents. A positive value of the specialization index in the jth industry in country k means that this country's patenting activity is more concentrated in industry $\mathrm{j}$ than is the case on average across the other eleven countries. As Figure 7 shows, the specialization indexes for these two countries are strongly negatively correlated: the scienceintensive industries of information technology, semi-conductors and biotechnology are in the top six industries by patent registrations for the USA and in the bottom four for Germany. Germany's patent specialization is highest in civil engineering and transport equipment industries which are in the bottom three in the USA. The scientific content of patents is relatively low in these industries.

How does the specialization pattern in innovation relate to the contrast between the contracting institutions in these two economies? One hypothesis is that some contracting institutions are better suited to some kinds of activities than others and hence, contracting institutions persist where they add value. Contracting institutions with low transactions costs are associated with common law codes, developed stock markets and dispersed ownership structures in large companies. These may be better suited to activities that rely on information disclosure and appraisal by many, such as is the case when radically new technologies are being developed (Allen and Gale, 1999). By contrast, for other activities where the involvement of related firms is necessary in the innovation process (e.g., other firms in the supply chain or firms in the same industry in the case of industry standard setting), detailed monitoring by a bank or by a large shareholder may be more efficient. This is likely to be the case in mature industries characterized by incremental innovation and the diffusion of platform technologies (e.g., Casper and Whitley, 2004). 
Figure 7 - Patent Specialization in USA and Germany, 1992-4

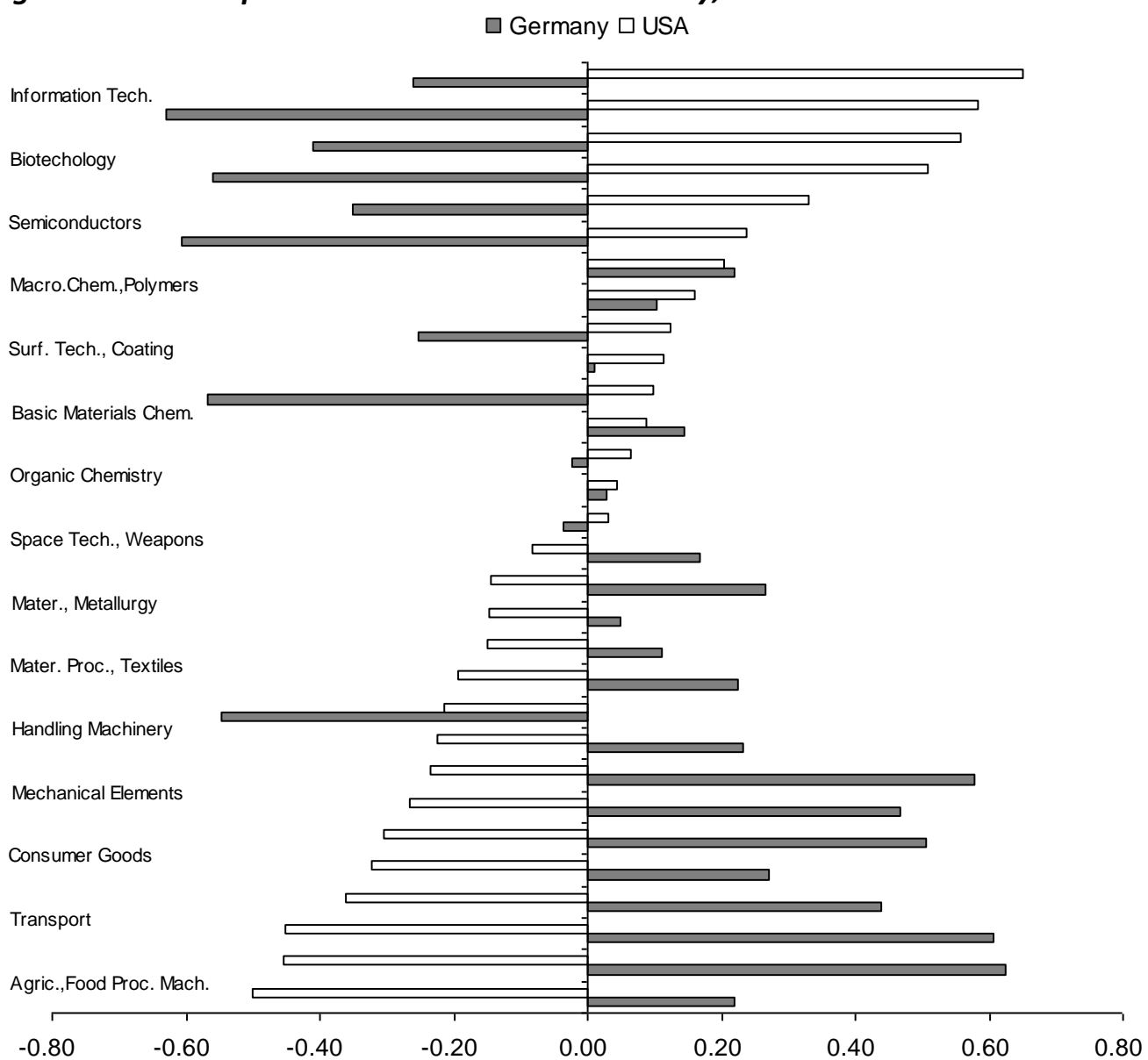

Source: Data supplied by Thomas Cusack, Wissenschaftszentrum Berlin.

In related work using industry level data for a sample of advanced economies, Carlin and Mayer (2003) find evidence consistent with the hypothesis that contracting institutions matter for comparative advantage. This is in line with the specialization pattern for the USA and Germany shown by the patent data. Carlin and Mayer find that for the advanced economies above average accounting disclosure is associated with above average growth and R\&D in industries that are skill-intensive and equityintensive. As an example, accounting standards in Denmark are below the average of the advanced economies whilst those in Finland are above average, i.e., there is less disclosure of information to shareholders in Denmark than in Finland. Bank and ownership concentration are similar. The above result would predict higher growth in Finland in equity dependent industries than in Denmark. In the study, the four industries with the highest level of equity dependence (measured in the USA, which is excluded from the econometric analysis so as not to bias the results) are 
instruments, electrical machinery, plastics and non-electrical machinery. In Finland, growth in all of these industries increased during the 1980s and rose again sharply in electrical machinery in the 1990s. By contrast, Denmark's growth declined in these four industries during both the 1980s and 1990s. Consistent with the theoretical predictions, equity dependent industries grew faster through a period of technological shocks in the country with the better accounting disclosure.

Traditional theories of comparative advantage would emphasize the natural resource endowment of Finland relative to Denmark as a source of advantage in resource intensive industries such as wood products and furniture. But the relative growth of these industries accelerated in Denmark, not Finland. Over this period it appears that measures of the financial structure of the two countries were more relevant to the comparative performance of their industries than were the underlying resource endowments. Allen et al. (2005) use cross country data to show an association between the strong presence of the stock market in the economy and the presence of knowledge and intangible asset based firms and between a 'bank-based' system and physical-asset intensive firms ${ }^{5}$.

The cross country data on institutions assembled over the past decade confirm that features associated with contracting institutions including ownership structures, creditor and minority shareholder protection, accounting standards, the size and turnover of the stock market and the concentration of the banking system vary widely across the rich countries. These differences also appear persistent, which may be due to the power of the vested interests that benefit from them ${ }^{6}$ and / or to the role these differences play in determining comparative advantage.

If reforms are to be properly designed and to have their intended effect, we need to understand the reasons for persistent differences in contracting institutions, the functions they perform and the forms of abuse to which they are open. This is highlighted by recent fraud cases in the USA and Europe, Enron in the US in 2001 and Parmalat in Italy in 2004. Coffee (2005) shows that in each case, the nature of the fraud is intimately related to the structure of ownership and the associated agency problem, which are in turn related to the contracting institutions in place. In the case of Enron, the fraud centred on the incentives for managers to manipulate earnings so as to influence the share price. Such incentives are strong in a dispersed ownership system where high powered incentive contracts for managers that link their compensation to the share price have become an important mechanism to align the interests of owners (the principal) and managers (their agents).

${ }^{5}$ Further evidence along these lines is presented in Binh et al. (2006).

${ }^{6}$ See Rajan and Zingales (2003) for a trenchant argument of this kind. 
By contrast in the case of Parmalat, the agency conflict is different. In the block-holder ownership system prevalent in countries with higher legal formalism, the agency conflict is not between the owners and the managers but between the minority and majority shareholders. The blockholder is a controlling owner with the incentive and the resources to directly monitor the manager, which diminishes the standard principal agent problem. Fraud takes the form of appropriation of resources by the block-holder (sometimes referred to as tunnelling) and is reflected in the manipulation of the balance sheet rather than the earnings statement.

In the case of Enron, a reform response was implemented quickly in the Sarbanes-Oxley Act of 2002. Given the nature of the fraud, the focus of the reform was on limiting the scope for earnings manipulation by managers. One aim was to improve the effectiveness of the 'gate-keepers', i.e., the auditors, securities analysts and credit-rating agencies in deterring earnings management (Coffee, 2005). Specifically, auditors now have to report to an independent audit committee rather than to management.

A less focused discussion has characterized reform proposals in Europe. Reform through regulation appears intrinsically more problematic in the block-holder system because it is the owner who perpetrates the fraud. This makes it more difficult to design improvements in the role of the auditors along the lines of Sarbanes-Oxley. The European Union itself faces a much more complex reform task than does the US once it is recognized that different variants of contracting institutions exist across its jurisdiction, which includes countries with common law and different variants of civil law (French, German and Scandinavian). A recent study by Dyck and Zingales (2004) provides estimates of the private benefits of control (i.e., the value extracted by controlling share-holders in excess of their stake) in firms across countries. Their findings confirm differences associated with legal origin, with higher private benefits in civil law systems than in common law ones. However, they find that the significance of legal origin is much diminished by the inclusion of proxies of other institutional checks and balances in particular, press freedom and norms of tax compliance.

One conclusion from this comparison is that if corporate governance reforms are to be well designed much more needs to be known about the role played by different contracting institutions in economic performance. Within the European context, diversity rather than harmonization of regulation is almost certainly appropriate so as to allow firms to locate and incorporate where they can make best use of their capabilities. This conclusion is reinforced to the extent that there is complementarity between aspects of the financial structure and, for example, the labour 
market or skill formation system ${ }^{7}$ and to the extent that non-financial institutions such as a free media and tax compliance can substitute for regulation.

\section{Conclusions}

Countries that have successfully developed as capitalist economies have solved the problem of the relationship between the state and the private sector better than other countries. Yet in other respects their current institutions differ markedly, with roots apparently stretching far back into history such as those defined by the nature of the legal system. There is some support for the idea that variation in contracting institutions is related to patterns of specialization and hence to comparative advantage across countries. If this is so, then reforms aimed at harmonization may have unanticipated effects on resource allocation and performance. It also seems that the pathologies associated with different contracting institutions vary and call for different reform remedies.

When the currency reform took place in West Germany in 1948 dramatic effects were observed not because the reform instantly created institutions where there were none but because it supplied the key to unblock the functioning of the pre-existing formal and informal institutions, including confirming the legitimacy of existing owners of firms. Transition in the former Soviet bloc countries has proved much slower and much more costly than policy-makers or economists anticipated. A view has emerged that this large-scale reform surprise was due to the neglect of the role of institutions in the initial analysis and design of the reforms. In this paper, I have attempted to put flesh on the bones of this argument by (a) noting the implications of the single track strategy in which old rules were abandoned altogether; (b) separating the role of property rights institutions from contracting institutions and emphasizing that successful capitalism requires getting the relationship right between the state and private agents; (c) highlighting the problem of finding effective owners for large firms and showing how foreign owners have filled the gap.

Better protection of foreign investors is a marker for good property rights institutions and progress in transition is consistent with this. However, it was not anticipated at the outset of transition that foreign owners would themselves play such a pivotal role in directly raising productivity. We now need to understand the implications of reliance on

7 Such arguments are set out in Hall and Soskice (2001) and Carlin (2009); in the latter, more recent data on ownership structures and corporate governance reforms are provided. 
foreign firms and to find out whether the nationality of owners matters for development. The interplay between the state, foreign owners and domestic agents in creating well functioning norms of behaviour remains to be understood. The findings to date suggest the following questions: Why are large domestic owned firms unable to learn more readily from their foreign-owned rivals? Is the weakness of regional convergence within transition economies (as illustrated, for example, in Figure 4) related to the role of foreign ownership perhaps because of its limited impact in improving institutions across the economy? What is the actual and potential contribution to aggregate catch-up of the new firm sector and is this where large indigenous domestically owned firms will emerge from? Transition economies joined the capitalist economy as it entered a phase of intensified globalization and much remains to be learned from their experiences. 


\section{References}

Abelshauser, W. (1975). Wirtschaft in Westdeutschland, 1945-1948. Stuttgart: Deutsche Verlags-Anstalt.

Abelshauser, W. (2004). Deutsche Wirtschaftsgeschichte seit 1945. Munich: C.H. Beck.

Acemoglu, D., \& Johnson, S. (2005). Unbundling Institutions. Journal of Political Economy, 113 (5), 949-995.

Acemoglu, D., Johnson, S., \& Robinson, J.A. (2001). The Colonial Origins of Comparative Development: an Empirical Investigation. The American Economic Review, 91 (5), 1369-1401. doi:10.1086/432166

Acemoglu, D., Johnson, S., \& Robinson, J.A. (2005). A Response to Albouy's: A Reexamination Based on Improved Settler Mortality Data. Mimeo. MIT and Harvard.

Albouy, D. (2005). The Colonial Origins of Comparative Development: a Reexamination Based on Improved Settler Mortality Data. Mimeo. University of California at Berkeley.

Allen, F., Bartiloro, L., \& Kowalewski, O. (2005). Does Economic Structure Determine Financial Structure? Mimeo. Wharton School.

Allen, F., \& Gale, D. (1999). Diversity of Opinion and the Financing of New Technologies. Journal of Financial Intermediation, 8 (1-2), 68-89. doi:10.1006/jfin.1999.0261

Bartelsman, E. J., Haltiwanger, J., \& Scarpetta, S. (2004). Microeconomic Evidence of Creative Destruction in Industrial and Developing Countries. IZA Discussion Papers, 1374.

Bevan, A., Estrin, S., \& Schaffer, M. (1999). Determinants of Enterprise Performance During Transition. Centre for Economic Reform and Transformation Working Paper, 99/03.

Retrieved from http://ideas.repec.org/p/hwe/certdp/9903.html

Binh, K.B., Park, S.Y., \& Shin, B.S. (2006). Financial Structure and Industrial Growth: Direct Evidence from OECD Countries. (January 2006).

Retrieved from SSRN: http: / / ssrn.com/abstract=891044

Blanchard, O. (1997). The Economics of Post-Communist Transition. Oxford: OUP.

Blanchard, O., \& Kremer, M. (1997). Disorganization. Quarterly Journal of Economics, 112 (4), 1091-1126. doi:10.1162/003355300555439

Borkin, J. (1978). The Crime and Punishment of I.G. Farben. London: The Free Press.

Bowles, S. (2004). Microeconomics - Behavior, Institutions and Evolution, Princeton: Princeton University Press. 
Buchheim, C. (1988). Die Währungsreform 1948 in Westdeutschland. Vierteljahrshefte für Zeitgeschichte, 36, 189-231.

Carlin, W. (1989). Economic Reconstruction in Western Germany, 1945-55: The Displacement of 'Vegetative Control'. In Turner, I.D., (ed.), Reconstruction in Post-War Germany, Oxford \& New York: Berg.

Carlin, W. (1996). West German Growth and Institutions. In Crafts, N., \& Toniolo, G., (eds). Economic Growth in Europe Since 1945. Cambridge: Cambridge University Press.

Carlin, W. (2009). Ownership, Corporate Governance, Specialization and Performance: Interpreting Recent Evidence for OECD Countries. In Touffut, J.P., (ed.) Does Company Ownership Matter? Efficiency and Growth. London: Edward Elgar.

Carlin, W., Charlton, A., \& Mayer, C. (2007). Multinational Ownership and Subsidiary Investment.

Retrieved from SSRN: http:/ / ssrn.com/ abstract=958505

Carlin, W., \& Mayer, C. (2003). Finance, Investment and Growth. Journal of Financial Economics, 69 (1), 191-226. doi:10.1016/S0304-405X(03)00112-0

Carlin, W., Schaffer, M., \& Seabright, P. (2004). A Minimum of Rivalry: Evidence from Transition Economies on the Importance of Competition for Innovation and Growth. Contributions to Economic Analysis E Policy, 3 (1), Article 17. doi:10.2202/1538-0645.1284

Carlin, W., Schaffer, M., \& Seabright, P. (2010). A Framework for CrossCountry Comparisons of Public Infrastructure Constraints on Firm Growth. CEPR Discussion Paper, 7662.

Casper, S., \& Whitley, R. (2004). Managing Competences in Entrepreneurial Technology Firms: A Comparative Institutional Analysis of Germany, Sweden and the UK. Research Policy, 33 (1), 89106. doi:10.1016/S0048-7333(03)00100-8

Coffee, J.C. (2005). A Theory of Corporate Scandals: Why the USA and Europe Differ. Oxford Review of Economic Policy, 21 (2), 198-211. doi:10.1093/oxrep/gri012

Dewatripont, M., \& Roland, G. (1996). Transition as a Process of Large Scale Institutional Change. Economics of Transition, 4 (1), 1-30. doi:10.1111/j.1468-0351.1996.tb00159.x

Djankov, S., \& Murrell, P. (2002). Enterprise Restructuring in Transition: A Quantitative Survey. Journal of Economic Literature, 40 (3), 739-792. doi: $10.1257 / 002205102760273788$

Dyck, A., \& Zingales, L. (2004). Private Benefits of Control: An International Comparison. Journal of Finance, 59 (2), 537-600. doi:10.1111/j.1540-6261.2004.00642.x 
Eichengreen, B., \& Ritschl, A. (1997). Winning the War, Losing the Peace? Britain's Recovery in a West German Mirror. Mimeo. University of California at Berkeley.

Erker, P. (1999). Einleitung: Industrie-Eliten im 20. Jahrhundert. In Erker, P. \& Pierenkemper, T. (eds.), Deutsche Unternehmer zwischen Kriegswirtschaft und Wiederaufbau - Studen zur Erfahrungsbildung von Industrie-Eliten. München: Oldenbourg.

Estrin, S., Hanousek, J., Kocenda, E., \& Svejnar, J. (2009). The Effects of Privatization and Ownership in Transition Economies. Journal of Economic Literature, 47 (3), 699-728. doi:10.1257/jel.47.3.699

Eurostat Regional breakdown of GDP per capita 1995-2006 (NUTS2) online from http:/ /epp.eurostat.cec.eu.int/

Feldman, G.D. (2001). Allianz and the German Insurance Business, 1933-45. Cambridge: Cambridge University Press. doi:10.1017/CBO9780511511844

Fohlin, C. (2005). The History of Corporate Ownership and Control in Germany. In Morck, R. K., (eds.) A History of Corporate Governance around the World: Family Business Groups to Professional Managers. NBER and University of Chicago Press.

Frei, N. (ed.) (2003). Hitlers Eliten nach 1945. Deutscher Taschenbuch Verlag.

Gerschenkron, A., (1962). Economic Backwardness in Historical Perspective. Cambridge, MA: Harvard University Press.

Griffith, R., Redding, S., \& Simpson, H. (2003). Productivity Convergence and Foreign Ownership at the Establishment Level. CEPR discussion paper, DP3765.

Groningen Growth and Development Centre and the Conference Board, Total Economy Database, various dates, http:/ / www.ggdc.net.

Hall, P., \& Soskice, D. (2001). An Introduction to Varieties of Capitalism. In Hall, P., \& Soskice D., (eds.), Varieties of Capitalism: The Institutional Foundations of Comparative Advantage. Oxford, UK: Oxford University Press.

Hanousek, J., Kocenda, E., \& Svejnar. J. (2007). Origin and Concentration: Corporate Ownership, Control and Performance in Firms After Privatization. Economics of Transition, 15 (1), 1-31. doi:10.1111/j.1468$\underline{0351.2007 .00278 . x}$

Horstmann, T. (1991). Die Alliierten und die deutschen Großbanken Bankenpolitik nach dem Zweiten Weltkrieg in Westdeutschland, Bonn: Bouvier Verlag.

Joly, H. (2000). Kontinuität und Diskontinuität der industriellen Elite nach 1945. In Ziegler, D., (ed.), Großbürger und Unternehmer, BÜRGERTUM - 
Beiträge zur europäischen Gesellschaftsgeschichte, Band 17, Vandenhoeck \& Ruprecht: Göttingen.

Kornai, J. (2006). The Great Transformation of Central Eastern Europe: Success and Disappointment. The Economics of Transition, 14 (2), 207-244. doi:10.1111/j.1468-0351.2006.00252.x

Krengel, R. (1958). Anlagevermögen, Produktion und Beschäftigung der Industrie im Gebiet der Bundesrepublik Deutschland von 1924 zu 1958. DIW: Berlin.

La Porta, R., Lopez-de-Silanes F., Shleifer, A., \& Vishny, R. (1997). Legal Determinants of External Finance. Journal of Finance, 52 (3), 1131-1150. doi: $10.2307 / 2329518$

La Porta, R., Lopez-de-Silanes, F., Shleifer, A., \& Vishny, R. (1998). Law and Finance. Journal of Political Economy, 106 (6), 1113-1155. doi: $10.1086 / 250042$

La Porta, R., Lopez-de-Silanes, F., \& Shleifer, A., (1999). Corporate Ownership Around the World. Journal of Finance, 54 (2), 471-517. doi:10.1111/0022-1082.00115

Maddison, A. (1995). Monitoring the World Economy 1820-1992. Paris: OECD.

Megginson, W.L., \& Netter, J.R. (2001). From State to Market: a Survey of Empirical Studies of Privatization. Journal of Economic Literature, 39 (2), 321-389.

Murray, M.P. (2006). The Bad, the Weak, and the Ugly: Avoiding the Pitfalls of Instrumental Variables Estimation. (October 2006).

Retrieved from SSRN: http: / / ssrn.com/abstract=843185.

North, D.C. (1981). Structure and Change in Economic History. New York: W.W. Norton \& Co.

North, D. (1993). Economic Performance Through Time. Nobel Prize Lecture.

http:/ / nobelprize.org/economics/laureates/1993/north-lecture.html

OECD (2005a). Statistics on Measuring Globalisation, Volume I: Manufacturing (AFA) and Volume II: Services (FATS), February 2005.

OECD (2005b). Measuring Globalisation OECD Economic Globalisation Indicators. Paris: OECD.

Pande, R., \& Udry, C. (2005). Institutions and Development: A View from Below. In the Blundell, R., Newey, W., \& Persson, T. (eds.), Proceedings of the 9th World Congress of the Econometric Society, Cambridge: Cambridge University Press. 
Pohl, M. (1974). Zerschlagung und Wiederaufbau der deutschen Grossbanken, 1945-1957. In Beiträge zu Wirtschafts- und Währungsfragen und zur Bankgeschichte 13, Frankfurt am Main 1974, S.21-32.

Qian, Y. (2003). How Reform Worked in China. In Rodrik, D. (ed.) In Search of Prosperity: Analytic Narratives on Economic Growth. Princeton: Princeton University Press.

Rajan, R., \& Zingales, L. (2003). Saving Capitalism from the Capitalists. New York: Random House.

Ritschl, A. (1985). Die Währungsreform von 1948 und der Wiederaufstieg der westdeutschen Industrie. Vierteljahreshefte fuer Zeitgeschichte, 33, 136165.

Roland, G., \& Verdier, T. (1999). Transition and the Output Fall. Economics of Transition, 7 (1), 1-28. doi:10.1111/1468-0351.00002

Roland, G. (2000). Transition and Economics: Politics, Markets and Firms. Cambridge Mass.: MIT Press.

Sabirianova, P., K., Svejnar, J., \& Terrell, K. (2005a). Distance to the Efficiency Frontier and FDI Spillovers. Journal of the European Economic Association, Papers and Proceedings, 3 (2-3), 576-586.

Sabirianova, P., K., Svejnar, J., \& Terrell, K. (2005b). Foreign Investment, Corporate Ownership, and Development: Are Firms in Emerging Markets Catching Up to the World Standard? IZA Discussion Papers, 1457.

Shirley, M., \& Walsh, P. (2000). Public versus Private Ownership: The Current State of the Debate. Washington D.C.: The World Bank. doi:10.1596/1813$\underline{9450-2420}$

Wiesen, J. (2001). West German Industry and the Challenge of the Nazi Past, 1945-1955. Chapel Hill: University of North Carolina Press.

Williamson, J. (1990). What Washington Means by Policy Reform. In Williamson, J. (ed.), Latin American Adjustment: How Much Has Happened? Washington D.C.: Peterson Institute for International Economics. 